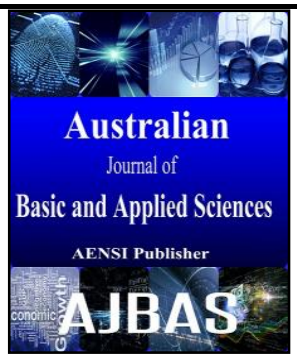

\title{
Impact of the living system and contacting mothers with their camel-calves during weaning period on growth indices, hematological and immunocompetence profiles
}

\author{
Reda, A. Abd-Elazem ${ }^{1}$; Abdel-Fattah M.S. ${ }^{1}$; Hashem A.L. ${ }^{1}$; Azamel A.A. ${ }^{1}$; Badawy, M.T. ${ }^{1}$ and Helal, A. ${ }^{2}$ \\ ${ }^{1}$ Department of Animal Physiology, Animal and Poultry Production Division, Desert Research Center, Cairo, Egypt \\ ${ }^{2}$ Department of Animal and Poultry Production, Faculty of Agriculture, Beni Suef University, Egypt
}

Address For Correspondence:

Reda, A. Abd-Elazem Department of Animal Physiology, Animal and Poultry Production Division, Desert Research Center, Cairo, Egypt E-mail: reda.drc@gmail.com

\section{ARTICLE INFO}

\section{Article history:}

Received 12 October 2017

Accepted 10 November 2017

Available online 29 November 2017

Keywords:

Camel-calves, Weaning, Maternal contact Growth indices, Hematological, Immunity

\begin{abstract}
A B S T R A C T
The study was carried out at Maryout Research Station - Desert Research Center Egypt and lasted for 28 days. Twenty female camel calves (Maghraby breed) were weaned using either calf-dam contact system (10 calves) or calf-dam separation system (10 calves) under two different living systems, where in each weaning system, six calves were kept in a group and four calves were kept individually. Calves were weaned at average 280 days of age with live body weight (LBW) of $236 \pm 0.2 \mathrm{~kg}$. Results indicated that calves remained with their dams (maternal contact system, MCS) had a pronounced effect on final body weight compared with calves completely separated (maternal separating system, MSS) from their dams $(245.34 \pm 0.34 \mathrm{~kg}$ versus $240.72 \pm 0.34 \mathrm{~kg})$. Also, calves in grouping system $(\mathrm{G})$ had greater $(\mathrm{P}<0.05)$ body weight gain compared with those kept in individually system (I) from day14 till the end of the study (day28). The calf-dam contact system increased total WBC's count for MSS-calves $\left(10.32 \times 10^{3} \mathrm{cell} / \mathrm{ml}\right)$ compared to MCS-calves $\left(9.67 \times 10^{3} \mathrm{cell} / \mathrm{ml}\right)$. Results indicated that the presence of dams with their calves had greater $(\mathrm{P}<0.05)$ blood $\mathrm{Hb}$ concentration $(13.84 \mathrm{~g} / \mathrm{dl})$ compared with calves completely separated from their dams $(13.34 \mathrm{~g} / \mathrm{dl})$, while RBC's count had greater values for MCS-calves $\left(8.19 \times 10^{6} \mathrm{cell} / \mathrm{ml}\right)$ compared with MSS-calves $\left(7.93 \times 10^{6} \mathrm{cell} / \mathrm{ml}\right)$.

It could be concluded that calf-dam contact and living systems during weaning period clearly influenced on growth indices and hematological responses of camel-calves and should be considered to let calves develop their resistance against weaning and psychological stresses, where the presence of dams with their calves for 14 days period post-weaning was very necessary, then gradually separation between them to reduce any negative effects on physiological and growth performance of calves.
\end{abstract}

\section{INTRODUCTION}

Weaning in domesticated mammals is characterized by the replacement of milk by solid feed stuffs. This definition evokes the idea that gathering mothers with their calves is mostly associated with nutrition, but psychological needs are also important (Orgeur et al, 1998). The opportunity of young-calves to suckling enough milk for covering its nutritional requirements and establishing the relationship between mother and its young (which is essential for the welfare of young) is crucial for post-weaning physiological and behavioral development (Atasoglu et al, 2008). Post-weaning performance is highly dependent on the quality and amount of feed available to young calves immediately after they removed from their dams (Wright and Pruitt. 2005). Stress associated with weaning of beef calves has been shown to elicit an acute increase in circulating levels of various blood constituents such as hematological parameters ( $\mathrm{Hb}, \mathrm{Ht}, \mathrm{RBC}$ 's and WBC's), the alterations in these blood constituents can be attributed to weaning method and the separation between calves and their dams during

Open Access Journal

Published BY AENSI Publication

(C) 2017 AENSI Publisher All rights reserved

This work is licensed under the Creative Commons Attribution International License (CC BY). http://creativecommons.org/licenses/by/4.0/ 
weaning period (Hickey et al., 2003 a; Campistol et al., 2013 and 2016). The ability of the calf to adapt to these stressors may affect subsequent on young health and performance (Duff and Galyean 2007). Consequently, reducing the negative impact of weaning and the other stresses (i.e. psychological and living system) associated with weaning stress is important in achieving an effective husbandry plan for flock health and productivity.

Previous study (LeNeindre, 1993) has assessed the effect on animal welfare of management stressors, such as isolation stress on productive performance during post-weaning period and reported that put group of animals together might be beneficial when considering the welfare and socialization of the calves (Gulliksen et al., 2009). Group living, containing 2 to 6 calves, provides more interactions and enriches their stability by adding stimulus (Stull and Reynolds, 2008).

Changes in the components of the blood picture are indicative of an attempt to recovery the homeostasis when abrupt physical condition and management process are imposed on animals; thus blood cells are very sensitive indicators of the patho-physiological responses in an animal (Jones and Allison. 2007). Hematological measurements are also important indicators regarding suboptimal growth parameters and other stress factors (Thrall, 2006).

Blanco et al, (2009) reported that leukocyte count was unchanged of weaned calves. On the contrary, Lynch et al. (2011) reported changes in total leukocyte count and their differential of beef calves as response to weaning stress.

Reducing the negative effects of some management factors (weaning system, living system) is important in preventing physiological and psychological stressors on the young calves and enhances their ability to adapt to these stressors. Therefore, the objective of this study was to comparing the post-weaning of camel-calves that were completely contact with their dams or were completely separated from their dams, in addition throw light on the importance of the other factors which have effect on calves responses during post-weaning period such as living system on growth indices, hematological and immune responses of weaned camel calves.

\section{MATERIALS AND METHODS}

\section{Animals and experimental procedure:}

Twenty female camel-calves of Maghraby breed with $236.76 \pm 0.224 \mathrm{~kg}$ initial live body weight (LBW) were weaned at 280 days of age under two different weaning systems by using either maternal contact system between calves and their dams or by Maternal separation system between them (psychological stress) as follows: I- Weaning with presence dams with their calves as maternal contact system (MCS): 10 calves were kept with their dams all the time during post-weaning period (28 days) where penned under two living systems (6 kept together in grouping pen, G vs. 4 kept in individually pens, I), as shown in picture No. 3.

II- Weaning with separating calves from their dams as maternal separation system (MSS): 10 calves were kept under two living systems (6 calves penned in two groups, and 4 calves penned in complete isolation in 4 replicates), as shown in pictures No. 4 and 5. The study was carried out at Maryout Research Station of the Desert Research Center (DRC), Egypt.

\section{Using anti-suckling:}

Using anti-suckling for calves under calf-dam contact system as mean prevent calves from nursing (see Pictures No.1 and 2) while allowing the calves and their dams remain together assuming that mothers will facilitates in decreasing weaning stress. The simple common form of anti-suckling is tie of thick cloth coated the udder of dam so that the calf cannot get the teat to nurse. This type of anti-suckling is of low cost and can be reused as it's a common use in desert areas.

All camel calves were fed commercial concentrate mixture to meet or exceed nutrient requirements for a post-weaning period to achieve adequate growth as suggested by Davis and Drackley (1998). Commercial concentrate feed mixture (CFM) was fed once a day in the morning (at 08:00 am). All the calves had clover hay (CH) ad libitum as roughage throughout the experiment period. The chemical composition of CFM and CH (on DM basis \%) are presented in Table (1). Proximate analyses were determined by the standard AOAC (2005), while nitrogen-free extract (NFE) was determined by calculating the differences. Fresh water was offered once daily. All calves, during pre and post-weaning periods were provided free-choice access to a salt-based trace mineral mix, which contain $12.0 \% \mathrm{Ca}, 9.0 \% \mathrm{~B}, 9.0 \% \mathrm{Na}, 0.30 \% \mathrm{Zn}, 0.15 \% \mathrm{Cu}, 0.05 \% \mathrm{Mn}, 0: 02 \% \mathrm{I}, 0.005 \% \mathrm{Co}$, and $0.004 \% \mathrm{Se}$; in a blocks form $(3 \mathrm{~kg}$ each).

\section{Live body weight $(\mathrm{LBW}, \mathrm{kg})$ :}

Live body weight was measured by platform digital balance on the day of weaning process and then weekly until day after weaning 28 . Total weight gain (TWG, $\mathrm{kg}$ ), average daily gain (ADG, g/h/d) and growth rate were calculated as follows:

- Growth rate,$(\mathrm{GR}, \%)=($ final weight- initial weight $) /($ initial weight $) * 100$ 
- Average daily gain, (ADG, gram/head/day) was calculated as the difference between two successive weights divided by the time period (days).

- Total weight gain, (TWG, kg) was calculated as the difference between final and initial weights.

Table (1) Chemical composition (on DM basis, \%) of concentrate feed mixture (CFM) and clover hay $(\mathrm{CH})$.

\begin{tabular}{cccccccc}
\hline Item & DM & OM & CP & CF & EE & Ash & NEF \\
\hline CFM $^{*}$ & 92.83 & 92.79 & 16.97 & 10.21 & 4.37 & 7.44 & 1.01 \\
CH & 90.77 & 84.91 & 14.84 & 24.83 & 1.78 & 15.03 & 43.52 \\
\hline
\end{tabular}

"CFM; concentrate feed mixture contained; 36\% yellow corn; $31 \%$ undecorticated cotton seed; $19 \%$ wheat bran; $7.5 \%$ rice bran; $2.5 \%$ molasses $; 3 \%$ limestone and $1 \%$ common salt.

\section{Blood hematology:}

Blood samples were collected by direct venipuncture of the jugular vein into $10 \mathrm{ml}$ vacutainer tubes containing Lithium heparin. Hemoglobin concentration $(\mathrm{Hb}, \mathrm{g} / \mathrm{dl})$ was estimated according to Drabkin and Austin (1932) as well as packed cell volume (PCV, \%) were immediately determined. In addition, the erythrocytes (RBC's, x10 cells $/ \mathrm{ml}$ ) and total leukocyte counts (WBC's, x10 $0^{3}$ cells $/ \mathrm{ml}$ ) were calculated. Blood hematology (Hb,PCV, RBC's and WBC's) were determined at the day of starting weaning $\left(\mathrm{D}_{0}\right)$ and on subsequent days (i.e. 7, 14, 21 and 28 days post-weaning). Blood smear slides for differential white cell counts were done using Wright's stain according to (Jain 1993). Percentages of each leukocytic cell type were calculated in relative to total WBC's count weekly.

\section{Statistical analysis:}

Data were analyses using General Linear Model (GLM) procedures (SAS, 2008). Analysis of variance for a repeated measures design where sources of variation included calf-dam contact system, living system and their interactions. Mean comparisons were evaluated by Duncan's Multiple Range Test (1955).

\section{RESULTS AND DISCUSSION}

\section{1-Effect of maternal contact system (Psychological Stress): \\ 1-1-Growth indices response:}

Growth indices in terms of live body weight (LBW), total weight gain (TWG) and average daily gain (ADG) of camel calves during post-weaning period are presented in Table (2). Concerning the effect of calf-dam contact system, results in table 2 revealed that, initial and final body weight for MCS vs. MSS groups were 236.99 and $245.34 \mathrm{~kg}$ vs. 236.55 and $240.72 \mathrm{~kg}$, respectively. The overall mean of body weight indicated that, there was a pronounced effect of presence of calves with their dams on overall mean of calves weight (240.23 $\mathrm{kg}$ ) compared with the completely separation between calves and their dams $(236.30 \mathrm{~kg})$. Mears and Brown (1997) reported that the absence of visual and tactile contacts is the first cause of stress in isolated lambs. Likewise, Price et al.(2003) found that, at 2 week post-weaning, calves under fence line contact weaning system had gained 95\% more weight than calves under total separation weaning system $(21.4 \mathrm{vs} .11 .0 \mathrm{~kg}$, respectively; $\mathrm{P}<0.05)$. In contrast, Orgeur et al. (1998) and Caroprese et al. (2006) reported that no significant difference in growth rate was observed in lambs weaned gradually or suddenly separation from their dams. This indicates that sudden separation from the dam does not consistently have negative impacts on lamb's performance, while In the present study, a significant effect $(\mathrm{P}<0.05)$ was observed in body weight between both MCS and MSS-calves, where MCS-calves tended to be better in final body weight. At the end of the study, MCS-calves were heavier $(\mathrm{P}<0.05)$ by $4.62 \mathrm{~kg}$ than MSS-calves. Interaction between time and maternal contact system was highly significant $(\mathrm{P}<0.01)$ and are important for evaluating the beneficial effect of presence of dams with their calves during at least seven days of post-weaning period.

Regarding average daily gain, the results stated that calves with MSS system (completely separation between their dams) had greater loss in daily weight gain $(-662.85 \mathrm{~g} / \mathrm{h} / \mathrm{d})$ compared with those under maternal contact system $(-298.60 \mathrm{~g} / \mathrm{h} / \mathrm{d})$ during the first week of post-weaning period. This finding shown that, weight gain of calves was highly sensitive to the stress induced by the presence or deprivation of dams during postweaning period. Similar results were observed by Lynch et al. (2011) who found that greater weight gains in calves that weaned under fence-line system compared to total separated calves during wk 1 and 2 of weaning.

In the present study results indicated that calves growth rate percentage (GR\%) from $\mathrm{D}_{0}$ till the end of study $\left(\mathrm{D}_{28}\right)$ were 3.52 and $1.76 \%$ for MCS-calves versus MSS-calves, respectively. These findings reflect the advantage of dam's presence effect on growth performance during weaning process of their calves. As shown in Table 2, average daily gain was usually higher in MCS-calves compared to MSS-calves except in last week of weaning period and its obvious that maternal effect become highly significant in the first 2 weeks of weaning process and decrease gradually hereafter. The MSS-calves try to compensate in the last week of this study but it 
still had lower average daily gain throw the whole weaning period which was $148.9 \mathrm{~g}$ compared with $298.2 \mathrm{~g}$ for MCS-calves.

Table (2): Effect of maternal contact system and living system on live body weight (LBW, kg), growth rate (GR, $\%$ ), total weight gain (TWG, $\mathrm{kg}$ ) and average daily gain (ADG, g/h/d) of weaned camel-calves

\begin{tabular}{|c|c|c|c|c|}
\hline \multirow{3}{*}{ Time } & \multicolumn{4}{|c|}{ LBW (kg) } \\
\hline & \multicolumn{2}{|c|}{ Maternal contact } & \multicolumn{2}{|c|}{ Living system } \\
\hline & MCS & MSS & G & I \\
\hline $\mathrm{D}_{0}$ (Initial weight $/ \mathrm{kg}$ ) & $236.99^{\mathrm{a}}$ & $236.55^{\mathrm{a}}$ & $237.21^{\mathrm{a}}$ & $236.33^{b}$ \\
\hline $\mathrm{D}_{7}$ & $234.90^{\mathrm{a}}$ & $231.91^{\mathrm{b}}$ & $234.50^{\mathrm{a}}$ & $232.30^{\mathrm{b}}$ \\
\hline $\mathrm{D}_{14}$ & $240.57^{\mathrm{a}}$ & $234.80^{\mathrm{b}}$ & $239.22^{\mathrm{a}}$ & $236.11^{\mathrm{b}}$ \\
\hline $\mathrm{D}_{21}$ & $243.33^{\mathrm{a}}$ & $237.40^{\mathrm{b}}$ & $242.34^{\mathrm{a}}$ & $238.34^{\mathrm{b}}$ \\
\hline $\mathrm{D}_{28}$ (Final weight) & $245.34^{\mathrm{a}}$ & $240.72^{b}$ & $245.90^{\mathrm{a}}$ & $240.17^{\mathrm{b}}$ \\
\hline Overall mean & 240.23 & 236.30 & 239.83 & 236.65 \\
\hline GR \% & 3.52 & 1.76 & 3.66 & 1.62 \\
\hline \multirow[t]{2}{*}{ SE } & & \pm 0.34 & & \\
\hline & \multicolumn{4}{|c|}{ TWG (kg) } \\
\hline \multirow[t]{2}{*}{$\mathrm{D}_{0}$ to $\mathrm{D}_{28}$} & 8.35 & 4.17 & 8.69 & 3.84 \\
\hline & \multicolumn{4}{|c|}{ ADG $(g / h / d)$} \\
\hline $\mathrm{D}_{0}$ to $\mathrm{D}_{7}$ & -298.60 & -662.85 & -387.14 & -657.14 \\
\hline $\mathrm{D}_{7}$ to $\mathrm{D}_{14}$ & 810 & 412.86 & 674.30 & 544.30 \\
\hline $\mathrm{D}_{14}$ to $\mathrm{D}_{21}$ & 394.30 & 371.43 & 445.71 & 318.60 \\
\hline $\mathrm{D}_{21}$ to $\mathrm{D}_{28}$ & 287.14 & 474.30 & 508.60 & 261.43 \\
\hline$D_{0}$ to $D_{28}$ & 298.21 & 148.93 & 310.35 & $\mathbf{1 3 7 . 1 4}$ \\
\hline
\end{tabular}

$\mathrm{MCS}=$ maternal contact system; MSS = maternal separation system; $\mathrm{G}=$ group living; $\mathrm{I}$ = individually living;

$\mathrm{SE}=$ standard error; $\mathrm{D}=\mathrm{Day} ;{ }^{\mathbf{a}, \mathbf{b}}=$ different letter within the same raw at $(\mathrm{P}<0.05)$

\section{2-1- Erythrocytes response:}

According to the effect of calf-dam contact system, results in table (3) indicated that the calves contact with their dams was significantly higher $(\mathrm{P}<0.05)$ in blood $\mathrm{Hb}$ and $\mathrm{RBC}$ 's count $\left(13.84 \mathrm{~g} / \mathrm{dl}\right.$ and $8.19 \times 10^{6}$ cell $/ \mathrm{ml})$ compared with calves deprived from their dams $\left(13.34 \mathrm{~g} / \mathrm{dl}\right.$ and $7.93 \times 10^{6} \mathrm{cell} / \mathrm{ml}$, respectively).

Significant variations $(\mathrm{P}<0.05)$ were found in the present measurements during weaning period, where $\mathrm{Hb}$ concentration increased significantly from $\mathrm{D}_{14}$ till the end of the study $\left(\mathrm{D}_{28}\right)$, while PCV and RBC's count started to increase earlier from $\mathrm{D}_{7}$ till the end of the study. Lynch et al. (2011) found that no differences $(P=0.53)$ in RBC's concentrations were found between steers weaned under fence-line (FL) system compared with steers weaned under total separation (TS) from their dams from $\mathrm{D}_{0}$ till $\mathrm{D}_{7}$ while values of all steers (FL and TS) increased $(6.8$ vs. $8.0 \pm 0.1 \times 10 \% \mathrm{ml} ; P<0.01)$ from $\mathrm{D}_{7}$ to $\mathrm{D}_{10}$. Moreover, O'Loughlin (2011) found that blood $\mathrm{Hb}, \mathrm{PCV}$ and RBC"s count was lower than baseline $(\mathrm{P}<0.01)$ on $\mathrm{d}_{1}, \mathrm{~d}_{7}$ and $\mathrm{d}_{14}$ in weaned calves as a response to weaning stress.

\section{3-1- Leukocytes response:}

The number and proportion of leukocytes in the blood represent their state of distribution in the body and the activation of the immune system in response to stresses. In addition, many studies had used the immune response, such as the ratio of neutrophil to lymphocyte, as an indicator of stress and immuno-supression in calves (Hickey et al. 2003).

Results in the present study indicated that calf-dam contact system had a highly significant effect $(\mathrm{P}<0.01)$ on total WBC's count, neutrophil and lymphocyte percentages while, there was no significant effect $(\mathrm{P}>0.05)$ of presence or absence of dams on monocytes, eosinophil and basophil percentages at any sampling time and remained constantly throughout the study (Table 4). Turner et al., (2003) reported that abrupt weaning results in greater increase in neutrophil:lymphocyte ratio compared with gradual weaning in foals. Also, O'Loughlin et al. (2011) reported that following exposure to weaning stress, total neutrophil/lymphocyte (N/L) ratio increased $(\mathrm{P}<0.01)$ in calves. Additionally, the earlier and more profound increase in neutrophil number and $\mathrm{N} / \mathrm{L}$ ratio together with reduced lymphocyte number in calves penned away, compared with calves penned near their dams post-weaning suggest that the former may be more sensitive to weaning stress.

Table (3) Means \pm SE of blood hemoglobin concentration (Hb), packed cell volume (PCV) and erythrocytes count (RBC's) of weaned camel-calves as affected by maternal contact system and living system during postweaning period.

\begin{tabular}{|c|c|c|c|c|c|}
\hline \multirow{2}{*}{ Traits } & \multicolumn{2}{|c|}{ Maternal contact } & \multicolumn{2}{|c|}{ Living system } & \multirow{2}{*}{ \pm SE } \\
\hline & MCS & MSS & $\mathbf{G}$ & I & \\
\hline $\mathrm{Hb}(\mathrm{g} / \mathrm{dl})$ & $13.84^{\mathrm{a}}$ & $13.34^{\mathrm{b}}$ & $13.58^{\mathrm{a}}$ & $12.66^{b}$ & \pm 0.21 \\
\hline $\operatorname{PCV}(\%)$ & $29.84^{\mathrm{a}}$ & $29.70^{\mathrm{a}}$ & $29.69^{b}$ & $31.64^{\mathrm{a}}$ & \pm 0.56 \\
\hline RBC's $\left(\mathbf{x 1 0}^{6}\right.$ cells $\left./ \mathbf{m l}\right)$ & $8.19^{\mathrm{a}}$ & $7.93^{\mathrm{b}}$ & $7.35^{\mathrm{b}}$ & $8.21^{\mathrm{a}}$ & \pm 0.19 \\
\hline
\end{tabular}

$\mathrm{MCS}=$ maternal contact system; MSS = maternal separation system; G = group living; I = individually living;

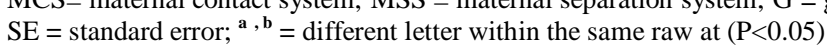


In MSS calf-dam contact system leads to increase the total WBC's count $\left(10.32 \mathrm{X} 10^{3} \mathrm{cell} / \mathrm{ml}\right)$ compared to MCS contact system $\left(9.67 \times 10^{3} \mathrm{cell} / \mathrm{ml}\right)$. In accordance, Campistol et al., 2013 and 2016) reported that during weaning, WBC count was higher significantly in separated steers from their dams compared with fence-line steers $\left(14.0\right.$ vs. $11.7 \times 10^{3}$ cells $/ \mathrm{ml}$; SEM $\left.=0.6\right)$. In addition, significant variation $(\mathrm{P}<0.05)$ were found during weaning period, where all steers shown greater WBC counts on days 7 and 14 compared with day 0 (14.0 and 14.5 vs. $11.0 \times 10^{3}$ cells $/ \mathrm{ml}$; SEM =0.9), respectively. Moreover, Myung-Hoo Kim et al. (2011) reported that there was no change in the concentration of white blood cells after weaning of Holstein calves kept in group pens without their dams and fed a concentrated mixture and forage.

Regarding the changes in differential WBC populations, neutrophil percentage was greater $(\mathrm{P}<0.05)$ and lymphocyte percentage was lower $(\mathrm{P}<0.05)$ in MSS-calves, therefore the N/L ratio was higher compared with MCS-calves. However, in the present study, the N/L ratio did not indicate immunodepression in any animals, nor did any calves show clinical signs of illness. There was a significant interaction $(\mathrm{P}<0.05)$ of calfdam contact system X time for total WBC's count, neutrophil and lymphocyte percentages. In agreement, O'Loughlin et al. (2011) reported that following exposure to weaning stress, total neutrophil/lymphocyte (N/L) ratio increased $(\mathrm{P}<0.01)$ in calves. Additionally, the earlier and more profound increase in neutrophil number and $\mathrm{N} / \mathrm{L}$ ratio together with reduced lymphocyte number in calves penned away, compared with calves penned near their dams post-weaning suggest that the former may be more sensitive to weaning stress. Hickey et al. (2003a) and O'Loughlin et al. (2011) suggested that the lack of contact with the dam following weaning may increase the stress load of calves. Previous study conducted by (Church and Hudson. 1999) have examined the effect of maternal separation under varying management regimes on blood WBC"s (neutrophil/lymphocyte (N/L) ratio) and reported that breaking the maternal bond is stressful to the calf by increase neutrophil/lymphocyte (N/L) ratio.

Lynch et al. (2011) reported that WBC's concentrations were found higher for steers weaned under fense-line (FL) system compared with steers weaned under total separation (TS) from their dams (13.4 vs. 11.6 \pm $\left.0.6 \times 10^{3} \mathrm{~mL} ; P<0.05\right)$. The reduction in lymphocyte subsets is most likely attributable to a redistribution of these cells from the peripheral circulation to immune compartments or tissues of greater importance during a stressful event. Trafficking of cells is an important and dynamic factor for effective cell-mediated immunity and stress has been shown to influence this process (Kehrli et al, 1999; Bauer et al, 2001 and Viswanathan and Dhabhar, 2005).

Table (4): Effect of maternal contact system and living system during post-weaning period on total leukocytes count and their differentiation (nutrophils, lymphocytes, monocytes, eosinophils and basophiles).

\begin{tabular}{|c|c|c|c|c|c|}
\hline \multirow{2}{*}{ Traits } & \multicolumn{2}{|c|}{ Maternal contact } & \multicolumn{2}{|c|}{ Living system } & \multirow{2}{*}{$\pm \mathrm{SE}$} \\
\hline & MCS & MSS & $\mathbf{G}$ & I & \\
\hline WBC's $\left(\times 1^{3}\right.$ cells/ml $)$ & $9.67^{b}$ & $10.32^{\mathrm{a}}$ & $9.41^{b}$ & $9.94^{\mathrm{a}}$ & \pm 0.36 \\
\hline Neutrophils \% & $51.8^{b}$ & $52.16^{\mathrm{a}}$ & $52.70^{\mathrm{a}}$ & $50.30^{\mathrm{b}}$ & \pm 1.04 \\
\hline Lymphocytes \% & 40.50 & 40.04 & $37.90^{\mathrm{b}}$ & $40.80^{\mathrm{a}}$ & \pm 1.01 \\
\hline Monocytes \% & 2.50 & 2.50 & $3.80^{\mathrm{a}}$ & $3.50^{\mathrm{a}}$ & \pm 0.23 \\
\hline Eosinophils \% & $4.70^{\mathrm{a}}$ & $4.80^{\mathrm{a}}$ & $5.10^{\mathrm{a}}$ & $4.90^{\mathrm{a}}$ & \pm 0.22 \\
\hline Basophils \% & $0.50^{\mathrm{a}}$ & $0.50^{\mathrm{a}}$ & $0.50^{\mathrm{a}}$ & $0.50^{\mathrm{a}}$ & \pm 0.19 \\
\hline
\end{tabular}

MCS = maternal contact system; MSS = maternal separation system; $\mathrm{G}$ = group living; I = individually living;

$\mathrm{SE}=$ standard error $^{\mathbf{a}}{ }^{, \mathbf{b}}=$ different letter within the same raw at $(\mathrm{P}<0.05)$

\section{2- Effect of living system:}

\section{1-2- Growth indices response:}

Data for growth indices as affected by living system are presented in (Table 2) the results indicated that, there was pronounced effect $(\mathrm{P}<0.05)$ of grouped calves on body weight $(245.90 \pm 0.14 \mathrm{~kg})$ compared with individually or isolated calves $(240.17 \pm 0.14 \mathrm{~kg})$ at the end of the study. At the first week after weaning, calves lost -1.14 and $-1.70 \%$ of their body weights for grouped calves and individually or isolated calves, respectively. This lost may be attributed to the effect of weaning shock and the abrupt shifting from liquid to solid feed. From $\mathrm{D}_{14}$ till the end of study $\left(\mathrm{D}_{28}\right)$ results in Table 2 revealed that grouped calves had heavier $(\mathrm{P}<0.05)$ body weight compared with the individually or isolated calves. Likewise, ADG of grouped calves were greater than the individually or isolated calves along the experimental period. These findings may be attributed to the positive effect of social environment where these calves are faster to adapt to solid diet consumption as a consequence of the physiological delay in rumen development and subsequently grew faster than calves deprived from the social environment. Several studies have reported increased weight gains for group-housed calves compared with individually housed calves during the milk feeding and weaning periods (Chua et al., 2002; Xicatto et al., 2002 and Tapki, 2007), although some other studies have reported no effect (Farevik et al., 2007) or even increased weight gains for singly housed calves (Terre et al., 2006). The higher weight gain for calves housed in groups is often attributed to social facilitation of feeding, an effect reported in many farm species (Hsia and Wood- Gush, 1984; Napolitano et al., 2003 and Wattanakul et al., 2005). The variability among studies may relate to 
differences in management (e.g., the number of animals per group and weaning method). Costa et al., (2016) concluded that social living for calves improve solid feed intake pre-weaning and help improve weight gain before and after calves are weaned from milk to solid feed. Babu et al. (2003) attributed this to cohabitation in group housed animals induced learning to eat solid feed earlier, and also at higher amounts compared to individually fed animals. Duve et al. (2012) found that pair-housed calves more quickly accessed concentrates and spent more time eating concentrates than individually housed calves when the space at the feed manger was limited.

Chua et al. (2002) reported that calves that had been paired showed less of weight at weaning than did individually housed calves. De Paula Vieira et al. (2010) reported that pair living during the milk-feeding stage reduces calf responses to weaning and improves performance after weaning when calves are housed in groups. On the contrary, Villeneuve et al. (2009) reported that lambs growth performance was unaffected $(\mathrm{P}<0.05)$ by the type of living system (pair versus single). A study of twin heifer calves and effects of isolation versus group rearing found no differences in average daily gain between isolated and group-reared calves (Purcell and Arave, 1991). In disagreement, Abd-Allah et al., (2015) reported that there is a slight increase in the final body weight and growth rate of Buffalo calves reared in individual crates than those reared in groups, while no significant differences were observed in growth performance during the experimental period.

\section{2-2- Erythrocytes response:}

Results in Table 3 stated that calves grouped living have significant $(\mathrm{P}<0.05)$ effect on blood $\mathrm{Hb}$ concentration $(13.58 \mathrm{~g} / \mathrm{dl})$ compared with individually-housed calves $(12.66 \mathrm{~g} / \mathrm{dl})$, but individually-housed calves increased significantly $(\mathrm{P}<0.05)$ both PCV $(31.64 \%)$ and RBC's count $\left(8.21 \times 10^{6}\right.$ cell $\left./ \mathrm{ml}\right)$ compared with calves grouped living $\left(29.69 \%\right.$ and $8.07 \times 10^{6}$ cells/ml for PCV and RBC's, respectively). There was an interaction $(\mathrm{P}<0.01)$ between a living system and time for blood $\mathrm{Hb}, \mathrm{PCV}$ and RBC's.

In agreement, Andrighetto et al. (1999) found that blood hemoglobin concentration was greater in group housed than individually housed calves (10.9 vs. $7.7 \mathrm{~g} / 100 \mathrm{ml}$; P < 0.01). However, Gottardo et al. (2005) reported that hemoglobin concentration was not affected by increasing the number of calves from 3 to 7 per pen.

Meizar. (2014) revealed that no differences $(\mathrm{P}=0.14)$ were found in $\mathrm{Hb}$ concentrations due to living of veal calves in groups of 2,4 , or 8 per pen $(9.0 \pm 0.1,8.5 \pm 0.2$, and $8.6 \pm 0.2 \mathrm{~g} / \mathrm{dl}$, respectively). However, Hb concentration was greatest $(\mathrm{P}<0.001)$ in all calves during the $1^{\text {st }}$ and $2^{\text {nd }}$ month than that on the $5^{\text {th }}$ month.

On contrary, Lakshman et al, (2009) reported that neither living system (G vs. I) nor feeding schedule affected the concentration of blood $\mathrm{Hb}$ and PCV of calves except on day 28, when $\mathrm{Hb}$ was significantly higher in the calves housed in individual pens. Similar effects of living system on hematological observations were also made earlier (Friend et al, 1985 and Fisher et al, 1997).

The obtained results stated that increased PCV and RBC values after individually living indicated living stress (individually or isolated) and this stress persisted until day 28 indicating chronic living stress. Throughout the study calves housed individually did not recover to their pre weaning values of PCV and RBC's values. Therefore, a social or familiar living is necessary in farm animal's husbandry.

\section{3-2- Leukocytes responses:}

With respect the effect of living system solely on total leukocytes count and their differential, results in Table 4 indicated that calves housed individually increased $(\mathrm{P}<0.01)$ total WBC's count $\left(10.23 \times 10^{3} \mathrm{cell} / \mathrm{ml}\right)$ compared with calves housed in groups $\left(10.07 \times 10^{3} \mathrm{cell} / \mathrm{ml}\right)$. In accordance, Hulbert and Ballou (2012), reported that calves housed individually had reduced performance and elevated total leukocyte counts. The results indicated that $\mathrm{N}$ and $\mathrm{L} \%$ in calves housed individually recorded the higher percentages $(52.92 \%$ \& $40.80 \%)$ compared with grouped calves $(50.58 \% \& 37.92 \%)$ at the end of study $\left(\mathrm{D}_{28}\right)$. Therefore, these changes in leukocyte probably reflect the higher effect of weaning stress combined with social-less (psychological effect) stresses. In contrast, a recent study performed by Cobb et al., (2014) who indicated that calves housed in groups of $3 \mathrm{had}$ more active neutrophils in peripheral circulation than individually housed calves.

Lynch et al. $(2010 ; 2011)$ reported that the weaning procedure can be an acute stressful event in young calves combing social, physical, nutritional and psychological stresses. Likewise, Hickey et al. (2003a) and Price et al. (2003) found alterations in immune function and hormonal mediators of stress still present at 7 days following abrupt weaning whereby the cows were suddenly removed from the calves, compared with fence-line system weaning, the N/ L ratio (1.50) on $\mathrm{D}_{7}$ post-weaning for I-calves compared with G-calves (1.4).

Paape et al. (2003) and O'Loughlin et al, (2012) mentioned that neutrophilia can partly be attributed to a surge of cortisol which may result in a series of physiological alterations to neutrophil function including the release of a large number of immature neutrophils from the bone marrow. 


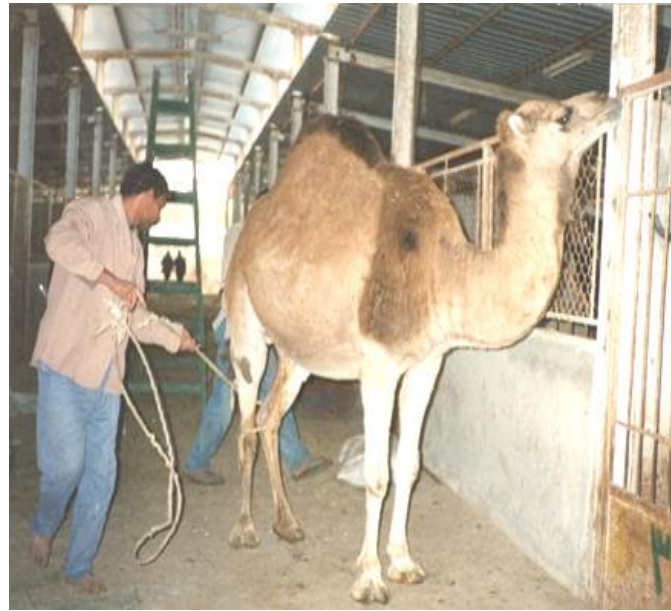

Picture (1)

The first step of preparing she-camel to coating their udder

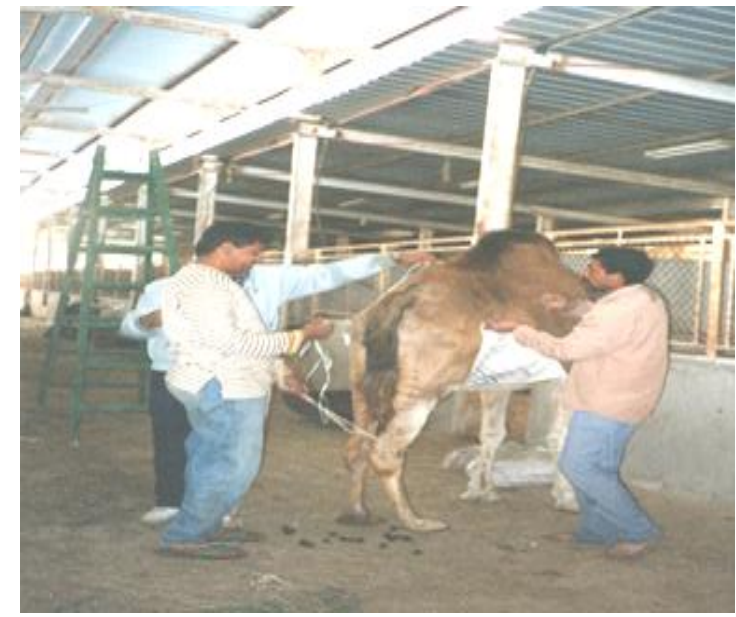

Picture (2)

Anti-suckling is tie of thick cloth coated the udder of dam

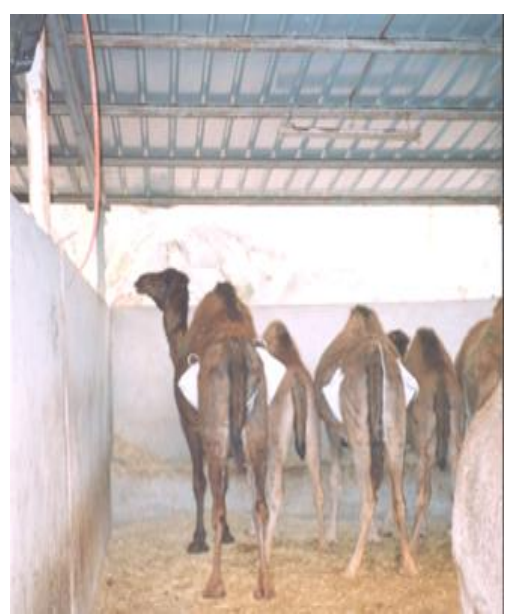

Picture (3)

Dams with their calves under completely contact system or maternal contact system (MCS) and kept as grouping system (G)
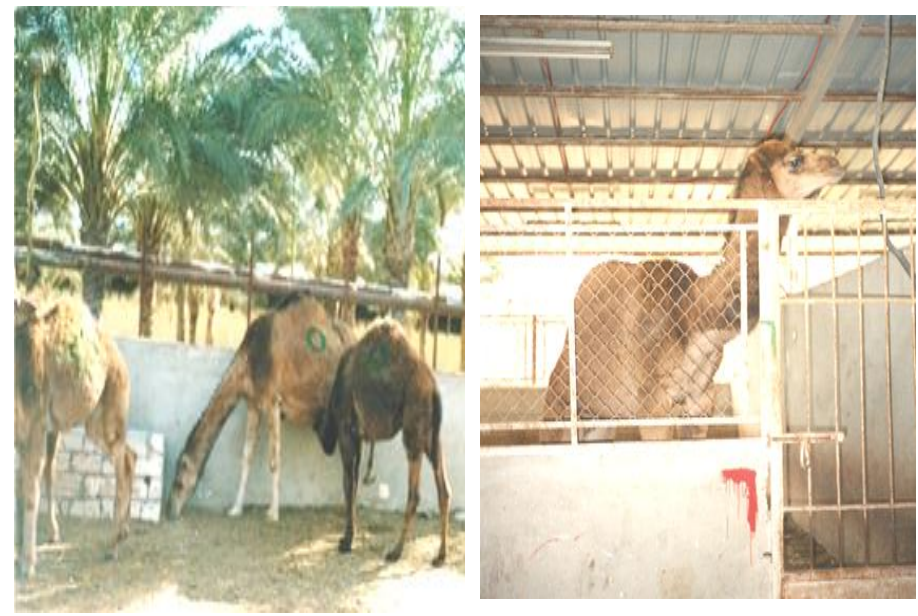

\section{Picture (4)}

Calves separated from their dams under completely separation system or maternal separation system (MSS) and kept as grouping sysytm (G)

\section{Picture (5)}

Camel-calf separated from their dam under completely separation system or maternal separation system and kept as individually system (I)

\section{CONCLUSION}

To minimizing the impact of management factors for camel calves, at the weaning time, the most important factor which might affect the performance characteristics is either allow the attachment between calves and their dams for 14 days at least during weaning process while preventing suckling, calves must gradually moving into a new social structure within a group of their peers. 


\section{ACKNOWLEDGEMENTS}

The researchers acknowledge the farm staff working at animal production sector, Maryout Research Station for their assistance with animal handling and management. It would have been very difficult to conduct this work without their positive cooperation. We gratefully thanks to Dr. Samir El-Sheikh, Researcher Professor in Animal Breeding Department, for his help in statistical analysis. Finally, we gratefully thank to the late AbdelFattah Rashed for his cooperation on analysis of animal diets.

\section{REFERENCES}

AOAC. 2005 Official methods of analysis association of Analytical chemists, 16th ed. Aoac. International , Washington, DC., USA.

Abd-Allah M. , M.Y. Elaref and A.I. Zanouny 2015. Influence of different managerial systems on performance and physiological responses of developing buffalo calves during fattening period. Egyptian J. Anim. Prod. (2015) 52(1):1-9.

Andrighetto, I, F.Gottardo, D. Andreoli, and G.Cozzi 1999. Effect of type of living on veal calf growth performance, behavior, and meat quality. Livest. Prod. Sci. 57: 137-145.

Atasoglu, C., I.Y.Yurtman , T. Savas, M. Gultepe and O. Ozcan 2008. Effect of weaning on behavior and serum parameters in dairy goat kids. Anim. Sci. J. 79,435-442.

Bauer ME, P. Perks, SL. Lightman, N. Shanks 2001. Are adhesion molecules involved in stress-induced changes in lymphocytes distribution Life Scie., 69:1167-1179.

Babu L. K., H. N. Pandey and A. Sahoo 2003. Effect of individual versus group rearing and feeding of different levels of milk and skim milk on nutrient utilization in crossbred calves. Asian-Aust. J. Anim. Sci, 16 (10) : 1455-1459

Blanco, M., I. Casasús, and J. Palacio 2009. Effect of age at weaning on the physiological stress response and temperament of two beef cattle breeds. Animal. 3:1.108-117.

Campistol C, H.G. Kattesh, J.C. Waller, J.D. Rawls EL Arthington, T.E. Engle, J.A. Carroll, G.M. Pighetti and A.M. Saxton 2013. Effects of two-stage and total vs. fenceline weaning on the physiology and performance of beef steers. J. Anim. Sci. 29:501-507.

Campistol, C., H. G. Kattesh, J. C. Waller, E. L. Rawls, J. D. Arthington, J. A. Carroll, G. M. Pighetti, and A. M. Saxton 2016. Effects of pre-weaning feed supplementation and total versus fenceline weaning on the physiological and performance of beef steers. Inter. J. of Livestock prod. Vol. 7(8):48-54.

Caroprese, M., F. Napolitano, M. Albenzio, G. Annicchiarico, M. Musto, and A. Sevi 2006. Influence of gentling on lamb immune response and human-lamb interactions. Appl. Anim. Behav. Sci., (99):118-131.

Chua, B., E. Coenen, J. van Delen, and D. M. Weary 2002. Effects of pair versus individual housing on the behavior and performance of dairy calves. J. Dairy Sci. 85:360-364.

Church, JS. and RJ. Hudson 1999. Comparison of the stress of abrupt and interval weaning of farmed wapiti calves (Cervus elaphus). Small Rum Res., 32:119-124.

Cobb, C.J., B.S. Obeidat, M.D. Sellers, A.R. Pepper -Yowell, D.L. Hanson, and M.A. Ballou. 2014. Improved performance and heightened neutrophil responses during the neonatal and weaning periods among outdoor group-housed Holstein calves. J. Dairy Sci. 97:930 -939

Davis, C. L., and J. K. Drackley 1998. The Development, Nutrition and Management of the Young Calf. Iowa State Press, Ames.

De Paula Vieira, A., M. A. G. von Keyserlingk , and D. M. Weary 2010. Effects of pair versus single housing on performance and behavior of dairy calves before and after weaning from milk. J. Dairy Sci. 93 :30793085.

Drabkin, D. L. and Austin 1932. Spectrophotometric studies: Spectrophotometric constants for common hemoglobin derivatives in human, dog and rabbit blood. J. of Biol. Chem. 719.

Duff, G.C. and M.L. Galyean 2007. Board-Invited Review: Recent advances in management of highly stressed, newly received feedlot cattle. Journalof Animal Science 85: 823-840.

Duncan, D.B. 1955 Multiple range and multiple F-test. Biometrics. 11:1-42.

Duve L. R., D. M. Weary, U. Halekoh and M. B. Jensen 2012. The effects of social contact and milk allowance on the response to handling, play behavior and social behavior in young dairy calves. J. Dairy. Sci, (95):6571-6581. 
Farevik, G., I. L. Andersen, M. B. Jensen, and K. E. Boe 2007. Increased group size reduces conflicts and strengthens the preference for familiar group mates in dairy calves (Bos taurus).Appl. Anim. Behav. Sci. 108:215-228.

Fisher AD, MA Crowe, DJ Prendiville, WJ. Enright1997. Indoor space allowance: effects on growth, behaviour adrenal and immune response of finishing beef heifers. Anim. Sci. 64, 53-62.

Friend TH, GR Dellmeier and EE. Gabur 1985. Comparison of four methods of calf confinement. I. Physiology. Journal of Animal Science 60, 1095-1101.

Gottardo, F., M. Dorigo, and G. Cozzi 2005. Effect of number of animals per pen on growth performance and meat quality of veal calves. Ital.J.Anim.Sci. 4 (Suppl. 2), 260-262.

Gulliksen, S., E. Jor, K.I. Lie, T. Loken, J. Akerstedt, and O. Osteras 2009. Repiratory infections in Norwegian dairy calves. American Dairy Science Association, 92, 5139-5146.

Hickey, M. C., B. Earley, and A. D. Fisher 2003a. The effect of floor type and space allowance on welfare indicators of finishing steers. Irish J. of Agri. and Food Res., 42, 89-100.

Hickey, M., M. Drennan, and B. Earley 2003.The effect of abrupt weaning of suckler calves on the plasma concentrations of cortisol, catecholamines, leukocytes, acutephase proteins and in vitro interferon-gamma production. J. Anim. Sci. 81:2847- 2855.

Hsia, L. C., and D. G. M. Wood-Gush 1984. Social facilitation in the feeding behavior of pigs and the effect of rank. Appl. Anim. Ethol. 11:265-270.

Hulbert, L. E. and M. A. Ballou. 2012. Innate immune responses and on health of individually reared Holstein calves after placement into transition-pens $23 \mathrm{~d}$ after weaning. J. Dairy Res.Vol.79, Issue (3):333-340.

Jones ML and RW.Allison 2007. Evaluation of the Ruminant Complete Blood Cell Count. Vet. Clin. North Amer.: Food Animal Practice, 23 (3):377- 402

Kehrli ME, Burton JL, Nonnecke BJ, Lee EK. 1999. Effects of stress on leukocyte trafficking and immune responses: implications for vaccination. Adv Vet Med, 41:61-81.

Lakshman K. Babu, Harnarain Pandey,Ramesh C. Patra and Artabandhu Sahoo 2009. Hemato-biochemical changes, disease incidence and live weight gain in individual versus group reared calves fed on different levels of milk and skim milk. Animal Science Journal 80, 149-156.

Le Neindre, P. 1993. Evaluating housing systems for veal calves. J. Anim. Sci. 71:1345-1354.

Lynch EM, Earley B, McGee M, Doyle S. 2010. Effect of abrupt weaning at housing on leukocyte distribution, functional activity of neutrophils, and acute phase protein response of beef calves. BMC Vet Res, 6(1):39.

Lynch, E.M., M. McGee, S. Doyle and B. Earley 2011. Effect of post-weaning management practices on physiological and immunological responses of weaned beef calves. Irish J. of Agric. and Food Res. 50:161174.

Mears, G.J. and F.A. Brown, 1997. Cortisol and $\beta$-endorphin responses to physical and psychological stressors in lambs. Can.J. Anim. Sci., (77): 689-694.

Meizar, E.M. 2014. Behavior and performance of veal calves in relation to group housing. Ph.D Thesis, Faculty of Veterinary Medicine Department of Animal Hygiene, Behavior and Management, Benha University, Egypt.

Myung-Hoo Kim,, Ji-Young Yang „, Santi Devi Upadhaya , Hyun-Jun Lee, Cheol-Heui Yun, Jong K. Ha. .(2011). The stress of weaning influences serum levels of acute-phase proteins, iron-binding proteins, inflammatory cytokines, cortisol, and leukocyte subsets in Holstein calves. J. Vet. Sci12(2), 151-157

Napolitano, F., G. Annicchiarico, M. Caroprese, G. De Rosa, L. Taibi, and A. Sevi. 2003. Lambs prevented from suckling their mothers display behavioral, immune and endocrine disturbances. Physiol. Behav. 78:81-89.

O’Loughlin Aran, David J Lynn, Mark McGee, Sean Doyle, Matthew McCabe and Bernadette Earley. 2012. Transcriptomic analysis of the stress response to weaning at housing in bovine leukocytes using RNA-seq technology. BMC Genomics, 13:250, 1-18.

O'Loughlin, A. 2011. Examination of the effect of weaning stress on the physiological and molecular regulation of immune function in circulating bovine leukocytes. Ph.D.Thesis, Livestock Systems Research Department National University of Ireland, Kildare, Ireland.

O’Loughlin, A., M. McGee, S. M. Waters, S. Doyle and B. Early 2011. Examination of the bovine leukocyte environment using immunogenetic biomarkers to assess immunocompetence following exposure to weaning stress. BMC Veterinary Research, 7:45, 1-13.

Orgeur, P., N. Mavric, P.Yvore, S.Bernard, R.Nowak, B. Schaal, and F. Levy 1998. Artificial weaning in sheep: consequences on behavioral, hormonal and immuno-pathological indicators of welfare. Applied Animal Behaviour Science 58, 87-103.

Paape MJ, DD Bannerman, X Zhao and J-W. Lee 2003. The bovine neutrophil: Structure and function in blood and milk. Vet Res, 34 (5):597- 627. 
Price, E.O., J.E. Harris, R.E. Borgwardt, M.L. Sween and J.M. Connor 2003 Fenceline contact of beef calves with their dams at weaning reduces the negative effects of separation on behavior and growth rate. J. of Anim. Sci., 81: 116-121.

Purcell, D. and C. W. Arave, 1991. Isolation vs. group rearing in monozygous twin heifer calves. Applied Animal Behaviour Science, 31, 147-156.

SAS Institue 2008 SAS/STAT software version 9.2 SAS Institute, Inc., Cary. N.C.,USA.

Stull, C. and J. Reynolds 2008. Calf Welfare. Vet. Clin. Food Anim., 24, 191-203.

Tapki, I. 2007. Effects of individual or combined housing systems on behavioral and growth responses of dairy calves. Acta Agric.Scand. 57:55-60.

Terre, M., A. Bach, and M. Devant. 2006. Performance and behaviour of calves reared in groups or individually following an enhancedgrowth feeding programme. J. Dairy Res. 73:480-486.

Thrall, M.A. 2006. "Veterinary Hematology and Clinical Chemistry" 2nd Edition, Blackwell Publishing, Lippincott Williams and Wilkins, Philadelphia.

Turner JL, Arns MJ, Minton JE, Pruitt JA.2003.Effects of abrupt vs gradualweaning on cortisol and immune function responses of foals. ProfAnim Sci. 19:55-61.

Villeneuve, L., H. Methot, D. Cinq-Mars, and R. Bergeron 2009. Effect of individual or paired housing during post-weaning on feed intake, growth rate and behaviour of lambs. Small Ruminant Research 85,99-104.

Viswanathan K. and FS. Dhabhar 2005. Stress-induced enhancement of leukocyte trafficking into sites of surgery or immune activation. Proc Nat. Acad Sci USA, 102:5808-5813. PubMed Abstract Publisher Full Text | PubMed Central Full Text

Wattanakul, W., H. L. Bulman, and S. A. Edwards 2005. The effect of creep feed presentation method on feeding behaviour, intake and performance of suckling piglets. Appl. Anim. Behav. Sci. 92:27-36.

Wright, C.L. and R. Pruitt 2005. Fence-line weaning for beef cattle - summary. South Dakota Beef Report Beef, pp. 1-2. ExEx2049.

Xicatto, G., A. Trocino, P. I. Queaque, A. Sartori, and A. Carazzolo. 2002. Rearing veal calves with respect to animal welfare: Effects of group housing and solid feed supplementation on growth, performance and meat quality. Livest. Prod. Sci. 75:269-280.

Frandson RD. 2003. Anatomy and Physiology of Farm Animals. Philadelphia: Lippincott Williams \& Wilkins. 462.

Costa, J. H. C., Keyserlingk, M. A. G., and Weary D. M. (2016). Invited review: Effects of group housing of dairy calves on behavior, cognition, performance, and health. J. Dairy Sci. 99:2453-2467. 